\title{
Prospects of forecasting innovative environment of the region on the basis of strategic management and controlling interaction
}

\author{
Irina Guseva \\ R.E. Alekseev Nizhny Novgorod State Technical University \\ Arzamas Polytechnic Institute \\ Department of Economy and Management in Mechanical \\ Engineering \\ Arzamas, Russia \\ N.I. Lobachevsky Nizhny Novgorod State University \\ Arzamas branch \\ Department of Economy and Management \\ Arzamas, Russia \\ iran_guseva@mail.ru
}

\author{
Olga Glebova \\ R.E. Alekseev Nizhny Novgorod State Technical University \\ Arzamas Polytechnic Institute \\ Department of Economy and Management \\ in Mechanical Engineering \\ Arzamas, Russia \\ gov-arzamas@yandex.ru
}

\author{
Pavel Dalekin \\ N.I. Lobachevsky Nizhny Novgorod State University \\ Arzamas branch \\ Department of Philosophy, Law and Social Disciplines \\ Arzamas, Russia \\ pasha.dalekin@mail.ru
}

\begin{abstract}
The article deals with the main issues of forecasting in innovative environment of the region. It defines ways of management and controlling interaction when forecasting in the hi-tech environment of the particular region, as well as tasks of these systems at each process step of forecasting. Ways of improving forecasting activity in the main directions of the innovative environment of the region with assistance of controlling are offered.
\end{abstract}

Keywords - forecasting, innovation, region, management, controlling, strategy, forecast

\section{INTRODUCTION}

Development of science and technology markets, growth of the level of integration processes in the world economy, total application of digital technologies contribute to the development of the sphere of innovation as one of the promising directions on the way to the development of the scientific and production potentials of the Russian Federation. Innovations in the current conditions of development serve as the basis for the formation of the scientific and technical reserve of the country, industry, region, municipality, they are aimed at developing scientific knowledge and increasing innovation capacity in all key business areas.

Existence of risks, uncertainties and fluctuations in the process of forecasting indicators in the independent area of regional innovation promotes necessity to develop and implement the latest methodological tools that take into account key specific features and problems in this area of research. In addition, the analysis of regional management shows that in the current situation, forecasting of innovations is accompanied by a number of problems, and functions of services in forecasting process are duplicated between various structural divisions of the executive authorities of the subjects of the Russian Federation.

At present, strategic innovation controlling is one of the fundamental platforms for supporting strategic management, which allows effective forecasting in the field of innovation in the main linear and functional areas of business.

Thus, forecasting of innovations in the region is focused on the formation, development and implementation of its innovation strategy and allows determining the prospects for the development of industries and business entities in the planned areas at the regional level of management. 
The field of innovation in the regional aspect is a complex subject of research, as it includes such functional areas as: financial, scientific and technical, personnel, resource, etc., which requires the definition of long-term development parameters of the subject of the Russian Federation.

Strategic innovation controlling performs methodical, analytical, information, coordination, control functions in the process of forecasting long-term indicators and implementation of federal and regional programs for the development of innovative activities.

\section{MATERIALS AND Methods (MODEL)}

Forecasting in the field of regional innovation as one of the stages in the development of science and production has a number of specific features and problems which include $[1,2,3]$ :

- lack of a clear strategy for innovative development and its main components;

- in the practice of regional management, long-term development programs are mainly evaluated on the basis of extrapolation methods;

- lack of scenarios and alternatives of development when forecasting in the field of innovative development of the regions;

- forecasting in the sphere of innovations in the regions is most often discrete;

- innovative forecasts do not have a clear relationship with other key projections, plans and programs for regional development;

- existence of risks, uncertainties and fluctuations in the field of innovation, which contributes to deterioration in quality of forecasts;

- lack of a specific approach in the course of forecasting innovation in the region, etc.

The authors outline the key features of forecasting in the field of innovation, allowing it to be positioned as a separate independent stage in the strategic regional management process [4]:

1. Forecasting innovative development of the region is a complex multi-level independent process within strategic management of the region, including collection and systematization of information resources, selection of tools, formation of forecast models, obtaining regulatory and actual forecasts, monitoring and evaluation of results, developing remedial actions and plans to achieve indicators.

2. In forecasting regional innovations, it is necessary to use: specific methodology and information, special tools which are not typical of other stages of strategic management of the region and have a rather narrow focus.

3. Process of forecasting innovations is complex and comprises multiple stages and levels, so qualitative forecasts cannot be made without taking into account impact factors and assumption analysis of a forecast model.

4. Due to its complexity and multistage nature, forecasting in the field of innovations should be carried out in the course of forming teams of regional specialists from various fields of knowledge (economic, financial, personnel, industrial, environmental, etc.) with the support of the service performing coordination functions of all participants in the process.

5. Forecasting, unlike other stages of strategic management of the region, assumes diversity of results in the form of pessimistic, optimistic and optimal forecasts, fluctuations and deviations.

6. Forecasts in the sphere of regional innovations are characterized by probabilistic nature of events, consequences, while remaining stages have valid, real results when being implemented.

7. Forecasting regional innovations is of particular importance and plays an important role in strategic management of the region, increases relevance of managerial decisions, and has an impact on the level of sustainability of the region as a whole.

In order to increase the efficiency and effectiveness of forecasting innovations in the region, to raise the level of reliability of forecasts for the implementation of long-term development programs, the authors suggest using achievements of strategic controlling in this area of research.

Implementation of strategic controlling of innovations in the practice of regional management and forecasting allows $[5,6,7]$ :

- reducing methodical, information, analytical, control and other pressures on regional management;

- reducing time, risks, uncertainties, resources in the process of forecasting regional innovations;

- creating a unified base for forecasting regional innovation environment in key areas on the basis of a single center;

- improving quality of the regional management process, which results in efficiency of performance of the subjects of the Russian Federation;

- receiving on-time reliable information when forecasting regional innovations, which is necessary for managerial decisions made by regional management;

- foreseeing results of regional resources management in the field of long term innovations on the basis of forecast models developed by service of controlling innovation, etc.

\section{RESULTS AND DISCUSSION}

Figure 1 shows process of strategic management and controlling interaction when forecasting in the innovation environment of the region, as well as directions of this interaction. 


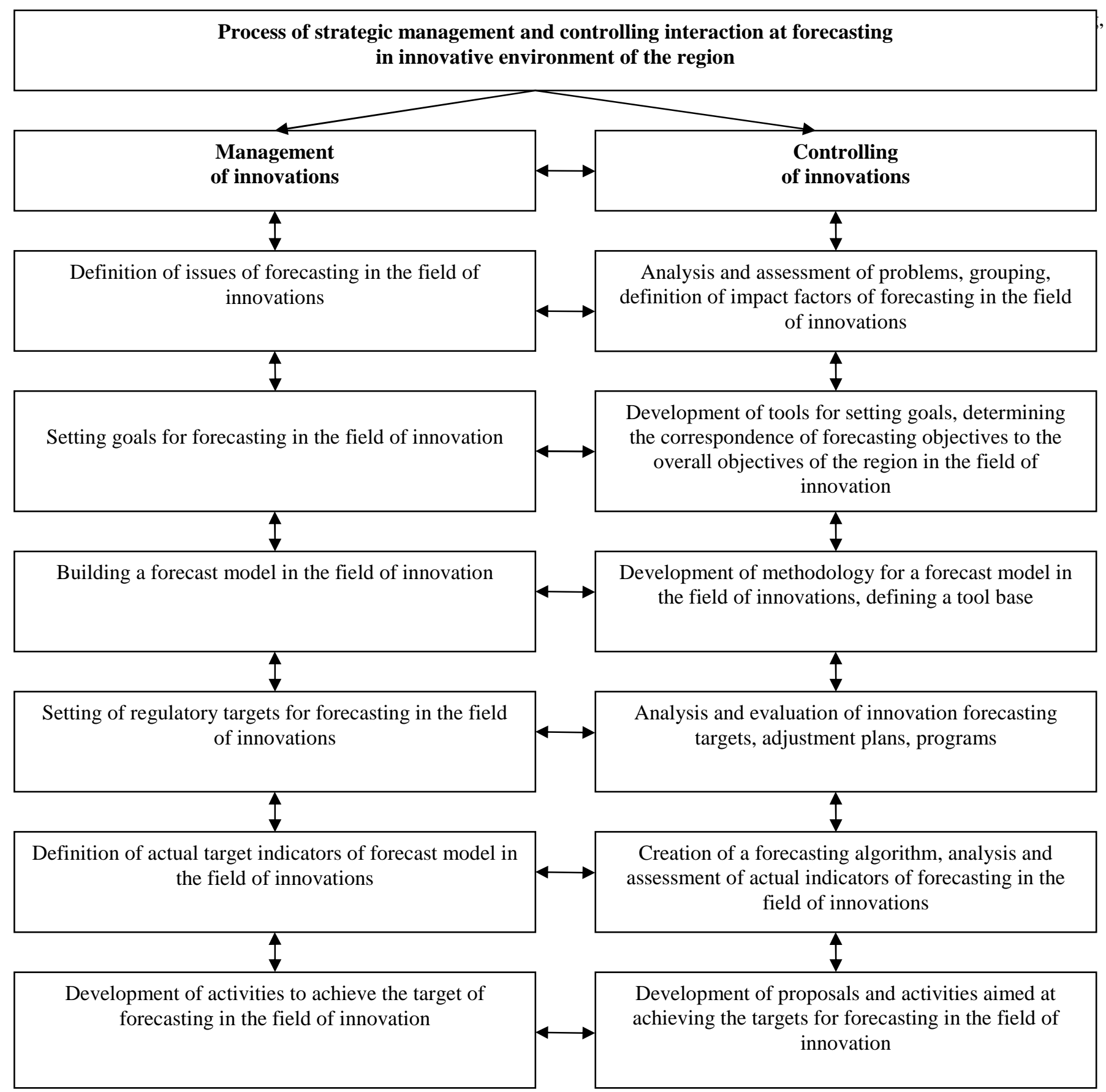

Fig. 1. Process of strategic management and controlling interaction when forecasting in innovative environment of the region

Process structuring of forecasting regional innovations with the support of controlling should, first of all, be based on rational delegation and distribution of authority, lack of their duplication and professional qualities of specialists of this service.

It should be emphasized that controlling in the field of innovations provides regional management of the enterprise with tools: methods, processes, algorithms, regulations,
In strategic management and controlling interaction in the process of innovative forecasting and planning of development of the specific region of the country, it is possible to single out main tasks which allow determining components of this integration on the basis of service support. Tasks of strategic management and controlling when constructing forecasts for innovative development of the subjects of the Russian Federation are presented by the authors in Table 1. 
TABLE I. Tasks of regional forecasting in the field of innovations

\begin{tabular}{|c|c|c|}
\hline \multirow{2}{*}{$\begin{array}{l}\text { Directions } \\
\text { of regional } \\
\text { forecasting } \\
\text { in the field } \\
\text { of innovations }\end{array}$} & \multicolumn{2}{|c|}{ Problems of regional forecasting in the field of innovations } \\
\hline & Management of innovations & Controlling of innovations \\
\hline $\begin{array}{l}\text { Issues } \\
\text { of regional } \\
\text { forecasting } \\
\text { in the field } \\
\text { of innovations }\end{array}$ & $\begin{array}{l}\text { - integrated monitoring of internal and external } \\
\text { environment of the region; } \\
\text { - identification and formulation of real and } \\
\text { potential issues of innovative development of the } \\
\text { region; } \\
\text { - identifying necessity for forecasting of regional } \\
\text { innovations, etc. }\end{array}$ & $\begin{array}{l}\text { - participation in monitoring environment of the } \\
\text { region; } \\
\text { - monitoring of trends in impact of factors on the } \\
\text { activity of the region; } \\
\text { - analysis of cause and effect of environmental } \\
\text { factors in the region; } \\
\text { - reporting on the results of impact of identified } \\
\text { environmental factors in the region; } \\
\text { - ranking of forecasting problems, etc. }\end{array}$ \\
\hline $\begin{array}{c}\text { Purposes } \\
\text { of regional } \\
\text { forecasting } \\
\text { in the field } \\
\text { of innovations }\end{array}$ & $\begin{array}{l}\text { - formulation of forecasting goals; } \\
\text { - transformation of goals into a system of tasks; } \\
\text { - definition of terms of achieving goals; } \\
\text { - appointment of persons in charge for achieving } \\
\text { goals and terms, etc. }\end{array}$ & $\begin{array}{l}\text { - methods of identification and formation of goals; } \\
\text { - ranking of forecasting goals; } \\
\text { - control of achieving forecasting goals; } \\
\text { - monitoring of execution period of forecasting } \\
\text { goals, etc. }\end{array}$ \\
\hline $\begin{array}{c}\text { Forecast model of } \\
\text { the region } \\
\text { in the field } \\
\text { of innovations }\end{array}$ & $\begin{array}{l}\text { - determination of characteristics, assumptions and } \\
\text { level of fluctuations; } \\
\text { - algorithm development of designing the forecast } \\
\text { model; } \\
\text { - approbation of the forecast model; } \\
\text { - managerial decision-making regarding further } \\
\text { implementation and application, etc. }\end{array}$ & $\begin{array}{l}\text { - formation of the tool base which meets the } \\
\text { requirements of regional management; } \\
\text { - development of proposals on the formation of the } \\
\text { forecast model; } \\
\text { - determination of forward and backward links of } \\
\text { the forecast model; } \\
\text { - control of the level of consistency, certainty and } \\
\text { reality of the forecast information; } \\
\text { - description of key parameters of models; } \\
\text { - formulation of instructions on the use of the } \\
\text { forecast model, etc. }\end{array}$ \\
\hline $\begin{array}{l}\text { Target regulatory } \\
\text { / target actual } \\
\text { indicators } \\
\text { of the region's } \\
\text { forecasting } \\
\text { in the field } \\
\text { of innovations }\end{array}$ & $\begin{array}{l}\text { - determination of time parameters for forecasting } \\
\text { targets; } \\
\text { - setting assumptions and conditions for the } \\
\text { formation of targets; } \\
\text { - formation of forecasting options; } \\
\text { - aggregation of forecasting indicators, etc. }\end{array}$ & $\begin{array}{l}\text { - calculation of regulatory and actual forecast } \\
\text { indicators; } \\
\text { - analysis of the level of fluctuations in indicators; } \\
\text { - assessment of the level of indicator consistency; } \\
\text { - analysis and estimation of the level of forecast } \\
\text { error; } \\
\text { - presentation of forecasting indicators (graphical, } \\
\text { chart, etc.), etc. }\end{array}$ \\
\hline $\begin{array}{l}\text { Activities aimed at } \\
\text { achieving } \\
\text { the region's } \\
\text { regulatory targets } \\
\text { in the field of } \\
\text { innovations }\end{array}$ & $\begin{array}{l}\text { - determining parameters of discrepancy between } \\
\text { target regulatory and target actual forecasting } \\
\text { indicators; } \\
\text { - determining parameters of selection of } \\
\text { forecasting indicators; } \\
\text { - determining direction of improvement of actual } \\
\text { forecasting targets, etc. }\end{array}$ & $\begin{array}{l}\text { - monitoring of forecasting indicators; } \\
\text { - analysis of deviations between regulatory and } \\
\text { actual forecasting targets; } \\
\text { - development of recommendations and activities } \\
\text { aimed at achieving regulatory targets, etc. }\end{array}$ \\
\hline
\end{tabular}

\section{CONCLUSION}

Analysis of the above-mentioned problems in the field of forecasting innovations in the regions gives evidence of the necessity for further research and resolution to these problems. The proposed structure of the process of forecasting in the field of innovation based on regional management and controlling interaction, identification of main tasks of these management systems at each stage, and description of the stages of forecasting in the field of innovations make it possible to raise level of management efficiency of innovative development of the particular region.

In scientific literature there are differentiated studies devoted to: forecasting innovations in the region, introduction of controlling in the executive bodies at federal, regional, local levels and in various functional areas. However, it should be noted that for the first time the authors propose procedure of 
forecasting in the sphere of innovations based on regional management and controlling interaction.

In this respect, development of methodological tools for forecasting innovations in the region with the support of controlling is one of the perspective directions in strategic development and management.

Further vectors for development of regional forecasting in the field of innovation with the conceptual use of controlling are:

- highlighting effective approaches to construct forecast procedures that meet key specifics of the particular regional development process;

- improving tool base of the particular region in forecasting in the field of innovations;

- developing measures to reduce risks, uncertainties in the process of constructing forecast models of innovation in the region;

- increasing level of consistency and transparency of forecasting procedures for innovative development of the region;

- taking into account goals of related parties and participants of regional innovation forecasting process, etc.

Thus, forecasting in the field of innovative development of the regions is a complex object of research and requires selection of specific approaches, development of effective tools aimed at taking into account characteristics, issues and problems in this area of research.

\section{References}

[1] I.B. Guseva, P.I. Dalekin, "Research and development on defense industry enterprises: modern problems", "Bulletin of Institute of Economy of the Russian Academy of Sciences", vol. 2, 2016, pp. 100114.

[2] I.B. Guseva, P.I. Dalekin, O.V. Kalenova, "Portfolio risk analysis of research and development of defense industry enterprises", "Innovations in management" vol. 9, 2016, pp. 18-22.

[3] O.V. Glebova, P.I. Dalekin, "Improvement of carrying out monitoring and assessment in the sphere of research and development", "Kazan science", vol. 9, 2011, pp. 50-52.

[4] I.B. Guseva, S.O. Sinitsina, "The principles of forecasting when determining need for administrative personnel", "Innov: online scientific magazine", vol. 2(23), 2016, pp. 2.

[5] I.B. Guseva, "Tool base of controlling (part 2)", "Controlling", vol. 1(25), 2008, pp. 16-25.

[6] I.B. Guseva, "Tool base of controlling", "Controlling", vol. 4(24), 2007, pp. 20-29.

[7] S.G. Falko, R.A. Assadulin, "Prospects of development of controlling", "Controlling", vol. 3(19), 2006, pp. 10-13. 